\title{
Editor's Preface
}

The essays presented here in this issue of Religion \& Theology create, on first impression, a rather mixed bag of submissions. They seem to range from work situated squarely within the field of theological studies to the field of the study of religion, and to cognate fields denoted by the "and" (as in religion and development), or what one might designate as the sociology of religion. Thus, some comment about and justification for the selection of articles presented here is in order.

As has been pointed out numerous times, Religion \& Theology is not a purely theological journal, and neither is it purely a journal for the study of religion, but rather is focused on the metatheoretical interface between the study of religion and the study of theology (i.e., the study of insider perspectives within the framework of outsider perspectives). As such, the journal pursues theorising of the conceptual architecture of both the study of religion and the study of theology in their relation to each other, as well as reflection on the methodological foundations and scholarly practices defining these. Therefore, Religion \& Theology does not do theology, but actually undermines theology, even as we aim, in addition, to redescribe the study of religion. On the journal homepage, we state clearly that the journal pursues inter- and trans-disciplinary studies in the fields of religion and theology, that is, encourages studies of insider language (= theology) in the context of outsider language (= religious studies), and both religious studies and theological studies as species of discourse formation (in the Foucaultian sense).

What this might mean in practice is well-articulated in the introduction to the volume, Discourse Research and Religion, ${ }^{1}$ as Jay Johnston and Kocku von Stuckrad set out Franz Eder's definition of religion and its implications: "Discourses are practices 'that systematically organize and regulate statements about a certain theme; by doing so, discourses determine the conditions of possibility of what (in a social group at a certain period of time) can be thought and said' (Eder 2006). Hence, discourse analysis does not only look at the textual and linguistic dimension of a topic but also at the practices that carry or change

1 Jay Johnston and Kocku von Stuckrad, "Introduction," in Jay Johnston and Kocku von Stuckrad, eds., Discourse Research and Religion. Disciplinary Use and Interdisciplinary Dialogues (Berlin: De Gruyter, 2021), 1-6, doi.org/10.1515/9783110473438. 
orders of knowledge. This includes institutions such as governments, courts, scientific associations, religious organizations, the media, as well as universities. These practices determine 'the conditions of possibility of what can be thought and said' from identifiable positions of power. That is why discourse research always pays attention not only to an analysis of what is being said or done, but also of who says or does it, and from which position and institutional background this is said or done."2 One can put it very succinctly as a study of the regulated and institutionalised practices of representation and signification (that includes that constructed domain that goes by the name of "religion"); an investigation of all the concrete operational sites of a given historical society's sense of self - its self-understandings, its self-representations, and its self-reinscriptions, the way in which these manifest in social and political institutions, public texts and literary traditions. This is what Religion \& Theology is about as a site for the investigation of how theological and religious studies discourses are "manufactured."

This focus, as expressed here, manifests in various ways in the following essays. Miriam Feldmann Kaye (“'Anatheism' from a Jewish Theological Perspective") engages with the modern God-beyond-God, or, after-god philosophical theology of anatheism, the late twentieth- and early twenty-first-century discourse of rescuing god-talk in a non-metaphysical manner in the long wake of the god-is-dead philosophical-theological tradition since the 196os. ${ }^{3}$ Anatheism is an attempt to discourse about God after the "death of God," standing in the "intellectual slipstream" of nineteenth-century philosophy (especially Hegel and Nietzsche) and its reception in twentieth-century philosophy and theology (e.g., Heidegger's critique of onto-theology; famously the theologians Gabriel Vahanian, Thomas Altizer, John A.T. Robinson, and, of late, Slavoj Žižek). While her focus is on a critique of a specific aspect of Richard Kear-

2 Jay Johnston and Kocku von Stuckrad, "Introduction," in Johnston and von Stuckrad, 3. The reference to Franz Eder is to his essay in the edited volume, Franz X. Eder, "Historische Diskurse und ihre Analyse - eine Einleitung," in Historische Diskursanalysen: Genealogie, Theorien, Anwendungen, ed. Franz X. Eder (Wiesbaden: vs Verlag für Sozialwissenschaft, 2006), 9-23; the definition by Eder is on p. 13 .

3 For a long overview of the history of this tradition, see Wilhelm Weischedel, Der Gott der Philosophen: Grundlegung einer philosophischen Theologie im Zeitalter des Nihilismus, 2 vols. (Darmstadt: Wissenschaftliche Buchgesellschaft, 2013 [1972]); see also, and especially, the essays collected in Jörg Salaquarda, ed., Philosophische Theologie im Schatten des Nihilismus (Berlin: De Gruyter, 1971). These two works resulted from the debates unleashed during the years 1962-1966 after the 1961 Kirchliche Hochschule Berlin lecture of Wilhelm Weischedel on "philosophical theology in the shadow of nihilism" - coinciding with similar movements in the English-speaking world, and part of the general intellectual culture of anti-metaphysics and anti-transcendence finding thus expression in the death-of-god theology. 
ney's use of Jewish interpretive tradition, Feldman Kaye's essay stands at the intersection of the very contemporary "theological turn" in Continental philosophy, Jewish hermeneutics of endless interpretation and endlessly deferred meaning, and what one might call "deconstructive mysticism."

By contrast, the two essays by Siphiwe Ignatius Dube ("The New Religious Political Right in Neo-Apartheid South Africa") and John Klaasen ("Religion and Development: The Idea of Personhood for Social Change") traverse very different ground. Both essays trace the impact of political discourses on religious discourses and practices, although from very different perspectives. Dube lays out very convincingly, and quite startlingly, the fusion of New Right political, social, and economic ideology with conservative Christianity (which supplies the moral foundation for the New Right's agenda for a political economy). This results in a theology of personal affirmation that encodes privileged middleclass aspirations, an encoding that aligns the discourse, the social and economic interests of the rising black middle-class with the politics of the White Right. Hence, the rise of a neo-apartheid Political Religious New Right, but which is now a kind of "class-apartheid," the phenomenon of a self-confident black middle-class that is no longer oriented to a theology of liberation (a vision of the social and economic upliftment of the majority), but constructing a spiritual home in "trophy churches," the outward manifestation of the flowering phenomenon of neo-Pentecostalism.

John Klaasen investigates the history of development discourse since the Second World War, especially since the formulation of the "Washington consensus." For the first decades after the war, it was this discourse on development (largely informed and shaped by what is now known as neoliberal economic theory, and represented by international institutions such as the World Bank and the International Monetary Fund at the time) that shaped Christian institutions' development aid programmes. In the aftermath of the Second Vatican Council and the "mainstreaming" of liberation theology, the tide turned with development increasingly seen as continued colonisation, hence the rise in farreaching reconceptionalising of what development can be (e.g., in the WCC Commission on the Churches' Participation in Development), with more participatory and emancipatory conceptions of development and an emphasis on concepts like "human flourishing." In this regard, Klaasen draws on two theological motifs as conceptual resources, namely, that of creation and the imago $D e i$, to argue for a new approach to development that is no longer understood as embedded in or encoding the discourses and practices of an extractiveexploitative economy. Drawing on a new theological anthropology, Klaasen argues for an understanding of humanity as non-hierarchical and inseparably part of creation, such that humans and the whole of the created order are man- 
ifestations of the divine (vestiges, "divine footprints"), and thus the site of the presencing of divine justice. This new anthropology with its vision of encompassing personhood (material and spiritual; rule not conceived as dominion over creation but as mutual caring and sustaining) transcends and transforms the materialism of secular approaches to development.

On the surface, Chris L. de Wet's essay, "Nemesius of Emesa on Desire, Pleasure, and Sex: A Case of the Medical Making of an Early Christian Sexual Culture," stands outside of the scope of the journal as defined above. Yet, on closer reading, De Wet does not offer merely a descriptive reading of Nemesius's discourses on desire, pleasure, and sex; the essay is in fact a "site for the investigation of how theological and religious studies discourses are 'manufactured." This reading of Nemesius is thus a study of one concrete operational site of a given historical society's sense of self. This essay is part of a larger project on the medicalisation of early Christian discourse, and should also be read in conjunction with earlier work of De Wet on Foucaultian discourses of the body. ${ }^{4}$ While this work is here focused on Late Antique Christian discourse formation, the study of the use of the medical science of antiquity to conceptualise Christian dispositions, habitus, and social mores and practices, makes it equivalent to investigating how contemporary cognitive science and neurobiology informs theoretical work on religion as well as certain themes in theological studies (like personhood). In a larger framework, its value lies in directing our understanding of religion as a sui generis discourse towards understanding such discourses as human constructions, in an "anthropocentric study of religion. ${ }^{5}$

In "Discourse on Pedagogy between Academy and the Public," Amanda L. du Plessis puts forward a proposal for curriculum transformation and renewal in South African institutions of higher education. She aims to make this relevant for both the study of religion as well as for theological studies, even though the proposal itself is almost exclusively oriented towards theology. Though explicitly a case study on the shaping of curriculum discourses at one institution (North-West University), these very same curriculum transformation dis-

4 Chris L. de Wet, “'Le devoir des époux': Michel Foucault's Reading of John Chrysostom's Marital Ethic in Histoire de la sexualité 4: Les aveux de la chair ([1982-1984] 2018)," Religion \& Theology 27, no. 1\&2 (2020): 114-151, doi.org/10.1163/15743012-bja10oo3; idem, "'Illius sponsi thalamus fuit uterus virginis': The Womb of Mary as Bridal Chamber in Augustine's Thought about Sexuality," Religion \& Theology 27, no. 3\&4 (2020): 299-328, doi.org/10.1163/1574301202703007 .

5 The term "anthropocentric study of religion" was coined by Willi Braun, see his Jesus and the Addiction to Origins: Toward an Anthropocentric Study of Religion, ed. Russell T. McCutcheon, NAASR Working Papers (Sheffield; Bristol, CT: Equinox, 2020). 
courses have played out at other institutions as well, and not only with respect to theology. At stake in these debates and discourses is the question of how to conceive of the function of the university and the relevance of higher education as such, especially as institutions still try to come to grips with the aftereffects of the \#RhodesMustFall, \#FeesMustFall, and \#ScienceMustFall movements of the student unrests between 2015 and 2019. This particular proposal explores what decoloniality can mean practically in an active student-centred approach supportive of the African Union's Agenda 263: The Africa We Want. It is a vision that strongly advocates incorporation of work-integrated learning, service learning, and community engagement. In this it stands at odds with other conceptions of the function of higher learning as not one of being a caretaker of community interests, but as critic of these - the other vision of the university as not an extension of society or as service provider to it, but as unaligned open space for investigation and critique without being immediately beholden to the economic and ideological investments steering social interactions in the domains of politics and economics outside of the university. ${ }^{6}$ It is exactly at this point that opinions diverge (where the debates on the commodification and instrumentalisation of knowledge and science rage in other forums), and where the "proposal for curriculum transformation" invites debate.

Mehraj Din's review essay, "Displacement of Manuscripts, Printing Revolution and Rediscovering Islamic Classics," considers the development of a new Islamic episteme (the term a nod to Michel Foucault) arising from the collection of Islamic manuscripts and texts, the growth of an Islamic printing tradition, as well as the emergence of a tradition of critical editorial work on such texts. The essay centres on Ahmed El Shamsy's monograph, Rediscovering the Islamic Classics, ${ }^{7}$ and traces how the collection, printing, and editing of Islamic texts transformed the intellectual heritage of Islam. But there is a broader implication that begs comparative theorising. Almost contemporaneous to the historical processes El Shamsy describes, a similar development took place in the Christian West - since the Renaissance, but especially since the beginning of the nineteenth century, the race to collect ancient Christian manuscripts (often through similar processes of division of manuscripts, illegal sales and acquisitions as El Shamsy describes), to collate and making critical

6 I refer to the, still important, question raised by Russell T. McCutcheon, Critics Not Caretakers: Redescribing the Public Study of Religion, Suny Series, Issues in the Study of Religion (Albany, NY: State University of New York Press, 2001).

7 Ahmed El Shamsy, Rediscovering the Islamic Classics: How Editors and Print Culture Transformed an Intellectual Tradition (Princeton, NJ; Oxford: Princeton University Press, 2020). 
editions took a similar form as in the Islamic world. And it had a similar effect: the explosion in the availability of other texts (critical editions or more popular translations) like Old and New Testament apocrypha, pre-canonical versions of texts that later became canonical (including the Dead Sea Scrolls with respect to the Old Testament; many unknown gospel fragments or divergent versions of known Gospels), the collection known as the Old Testament Pseudepigrapha, the discovery of the Nag Hammadi Coptic Gnostic library, early Christian literature encompassing a wide range of texts from the Apostolic Fathers to church fathers, all these almost completely redrew the contours of how one should now conceive of Christian origins, the formation of early Christian tradition, and the social histories of early Christian cult groups and movements (in fact: it puts in question what Christianity is); not to speak of how early Christians related to their Graeco-Roman context and religious heritage and continued to be bound (more or less) to their Jewish heritage.

Different foci, topics and themes as these essays address nonetheless, these essays - read together - give substance to the focus of Religion \& Theology: not merely descriptive, but analytical, explanatory, and retheorising studies that beckon from the border regions of metatheory and transdisciplinarity.

Gerhard van den Heever

Executive Editor: Religion \& Theology 